B. C. Семенов [V. S. Semenov] ${ }^{1}$

O. В. Семенова [O. V. Semenova $]^{2}$

УДК $364.255,172.2$

\title{
ДЕЯТЕЛЬНОСТЬ АДМИНИСТРАТИВНО-УПРАВЛЕНЧЕСКИХ И ОБЩЕСТВЕННЫХ СТРУКТУР В УСЛОВИЯХ ПРИРОДНЫХ КАТАСТРОФ
}

\section{ADMINISTRATIVE-MANAGEMENT BODIES AND PUBLIC ORGANIZATIONS ACTIVITIES IN NATURAL DISASTERS}

'ФГБУН "Федеральный исследовательский центр Южный научный центр Российской академии наук" (IOIЩ PAH), 344006, Ростовская область, г. Ростов-на-Дону, Россия/Federal Research Center "Southern Scientific Center of the Rus-

Academy of Sciences" (SSC RAS), 344006, Rostov Region, Rostov-on-Don, Russia; e-mail: semenov_unc@mail.ru

${ }^{2}$ ФБУН "Федеральный исследовательский центр Южный научный центр Российской академии наук" (IOІІІ PAН), 344006, Ростовская область, г. Ростов-на-Дону, Россия/Federal Research Center "Southern Scientific Center of the

Academy of Sciences" (SSC RAS), 344006, Rostov Region, Rostov-on-Don, Russia; e-mail: oliko_sov@mail.ru

Аннотация. В статье расслатривается и оценивается деятельность административно-управленческих струкmур, компаний и общественных организаций в процессе предупреждения и локализации последствий опасных природньх явлений

Материальи и мемоды, результаты. Aвторь констатируют рост маситабов и учаиение стихийньх бедствий, наруиаюиих сочиальную и экономическую деятельность населения в мире.

Для Юга России наиболее характерны проявления водной стихии, поэтому исследования сосредоточень преимущественно в прибрежньх зонах. Целью статьи является анализ деятельности органов власти и управления, различньх компаний, общественных организаций по предупреждению и локализации последствий опасньх природньх явлений. Включенное наблюдение реакции органов власти и инфраструктурных компаний на природный катаклизм, -ураган и наводнение в региоле Больиого Сочи, позволило авторам сделать эмпирические выводь и сформулировать предметнье рекомендации по управленческой деятельности в условиях чрезвычайной ситуации, прежде всего, относительно улуииения обслуживания пассажиров дальних рейсов, и информаџионного обеспечения граљдан в регионах, затронутьх стихией.

Заключение. Авпорь полагают необходимьм создавать компьютернье модели стихийньх бедствий для отдельных населенных пунктов, на основе которьх отрабатывать варианты развития угроз безопасности населения и фориировамь эффективнье сценарии реализации необходимьхмер.

Ключевые слова: опасное природное явление, стихийное бедствие, чрезвычайная ситуация, органы власти и управ.ления, транспортное сообщение, алгоритмы противодействия стихии.

Abstract. The article examines and evaluates the activities of administrative structures, companies and public organizations in the process of preventing and localizing the consequences of natural hazards.

Materials and methods, results. The authors note the increase in scale and frequency of natural disasters disturbing social and economic activities of population in the world.

The most typical features for the South of Russia are water-related disasters; that is why the studies focus mainly on the coastal zones. The goal of the article is to analyze the activities of on warning, prevention, and localization of consequences of natural hazards. The observation government and administration, various companies, public organizations of the authorities and infrastructure companies reaction to a natural disaster - the flood and storm in the Big Sochi Region - allowed the authors to draw empirical conclusions and formulate specific recommendations for management under emergency situations, primarily for the improvement of services for long-haul flights' passengers and information providing citizens in regions affected by the disaster.

Conclusion. The authors consider it necessary to create computer simulations of natural disasters for specific settlements to consider various scenarios of threats to population's safety in order to develop the most effective disaster prevention and reduction measures.

Key words: natural hazard, natural disaster, emergency, government and transport authorities, traffic, algorithms for counteracting to disaster.

Introduction. The studies of recent years confirm the increase in the scale and number of natural disasters that create security threats that disrupt the social and economic activities of the world's population. Specialists of the European Geophysical Union estimate the global damage caused by natural disasters from the beginning of the 20th century to 2015 in the amount of $\$ 7$ trillion, more than 8 million people became their victims [1]. It is estimated that more than $40 \%$ of the world's catastrophes are floods. A similar structure of damage is also characteristic of the South of Russia; therefore, most relevant studies of the Southern Scientific Center of the RAS are concentrated in coastal zones. A significant number of natural hazards take place in the region: floods, storms, hurricanes, temperature drops, tornadoes, dust storms and others [2, p. 6]. 
The purpose of the article is to analyze the activities of administrative and managerial structures, transport, infrastructure and other companies, authorities and local governments of various levels, units of political parties and public organizations in the process of preventing and localizing the consequences of natural hazards. Based on empirical conclusions, author's proposals are formulated for the organization of managerial processes. Particular attention is paid to the speed and quality of restoration and establishment of transport links after an emergency, life support systems, maintaining law and order, information coverage of the situation and steps taken by management structures.

In a modern "risk society", new technologies give rise to new dangers, depending on social relations and processes [3, p. 23]. The volume of technological and social risks is growing, it enhances the negative impacts of natural hazards, generates latent effects, including global ones. A comprehensive study of the relationship between hazardous natural phenomena and social processes in the coastal zone of the southern seas is one of the key areas of scientific activity of the SSC RAS. This problem requires study since the elements can affect the social situation, exacerbating problems, but also helping to show administrative and managerial shortcomings, stimulating the adoption of necessary measures. Man-made impact also transforms the natural environment. Energy raw materials, transport communications and recreational resources are concentrated in the southern region. Various ethnosocial systems, religious and other structures are intertwined here. At the same time, acute conflicts and unresolved problems remain for many years. Under such conditions, empirical data on specific natural disasters, measures of managerial and other structures in localizing negative consequences, eliminating damage, as well as summarizing the experience gained and developing algorithms for countering the elements are of particular importance. The task of collection and analysis of these materias is to identify patterns in the mutual conditionality of natural and social processes in the coastal zone of the southern seas.

Materials and methods, results. In modern Russia, the localization and elimination of the consequences of natural hazards is carried out on the basis of a set of administrative and legal measures. So, by the Federal Law of December 21, 1994 No. 68-FL "On the Protection of the Population and Territories from Natural and Technogenic Emergencies", an emergency situation is defined as the situation prevailing in a certain territory as a result of negative phenomena of a natural and technogenic (man-made) phenomena. Emergencies are subdivided into situations of a natural, technogenic and social character, and are classified according to the severity of the consequences and the distribution of negative factors. Responsible structures and the procedure for taking urgent legal, organizational, technical and other measures to ensure public order and safety, eliminate the negative consequences of the natural hazard are regulated by Federal Law dated December 28, 2010 No. 390-FL "On Security". The Russian Emergencies Ministry has special powers to solve problems in the field of protecting the population and territories from natural and man-made disasters, acting on the basis of Decree of the President of the Russian Federation of July 11, 2004 No. 868 "Issues of the Ministry of the Russian Federation Issues of the Ministry of the Russian Federation for Civil Defense, Emergencies and Disaster Management. "

In order to unite the efforts of the central and regional authorities, as well as institutions for the prevention and elimination of emergencies, by resolution of the Government of the Russian Federation of 05.11.1995 The Unified State System for Prevention and Response to Emergencies was created, which unites government bodies and structures related to ensuring public safety in emergency situations.

Nature creates new, often unforeseen risks and threats to security, which makes society seek new means of counteraction. According to Russian and foreign experts, it is most efficient to stop natural hazards at the local community level, adequate to local needs, both in the village and in the city [4, p. 14]. Self-organization of citizens allows us to find non-standard ways of preventing damage and counteracting the disasters. Measures taken by governments and departments are more critically evaluated, since, according to foreign colleagues, they are usually sporadic and are a late response to a fait accompli. Experts also note that centralized measures of government are more expensive than the development of local capabilities to counter the disasters.

Practice shows that the most complete and objective information about the natural hazards can be obtained during the expeditions, during interviews with eyewitnesses, thanks to a direct visit to the emergency areas. The materials of the expeditions, together with the data of the archives allow us to draw informed conclusions and proposals. Of particular interest are the observations of specialists in the emergency zone. So, one of the authors of this article, having arrived at a conference at the Sochi Research Center, witnessed a hurricane and flood on October 24-25, 2018 in Greater Sochi. It gave the opportunity to collect materials about the natural disaster, which became a test for residents and guests of the resort region, as well as outlining a number of problems requiring organizational and managerial response. Field research materials were collected through observation, photo and video recording, interviewing citizens and heads of various structures, collection of printed materials, etc.

The natural disaster affected the Tuapse and Absheron districts, Lazarevskoye, Sochi, Adler. In total, about 30 settlements, located mainly on the coast to the south of Tuapse were flooded, and road and rail links with the rest of the Krasnodar Territory were disrupted. A downpour, a gale, and a debris flow coming down from the mountains washed away the railway embankment, destroyed the highway and the bridge over the Tsypka River in the Tuapse region. Natural disaster caused significant damage to coastal villages, destroyed their electricity, gas and water supply.Over 1900 houses were completely or partially flooded [5]. Head of Civil Defense and Emergencies Department of the Krasnodar Territory S.E. Kapustin reported about six victims of the disasters. However, in the reports of the regional department of 
the Ministry of Emergencies, the disaster is indicated as a set of adverse meteorological phenomena, which means less danger than a dangerous event [6].

The most difficult situation, which affected several thousand people, has developed on the railway. The departure of 36 long-distance trains was canceled [7]. This created the prerequisites for a panic among passengers, most of whom were vacationers returning home. Representatives of Russian Railways Company at first could explain nothing to hundreds of people who had accumulated at the station. The most mobile and wealthy people used the Internet and bought tickets for airplanes flying from Adler airport. However, there was a few of those. plane tickets were quickly sold out, in the next two days it was almost impossible to buy them. Airplane tickets were quickly sold out, in the next two days it was almost impossible to buy them. According to eyewitnesses, prices for flights to Krasnodar by October 25,2018 rose to 25 thousand rubles per person [8]. Greater Sochi, which has the status of an all-Russian resort even during the off-season period, had serious problems, most acute in the violation of transport links. So there was a regional scale crisis situation.

In such conditions, the actions of government bodies and managerial structures of transport and other communications become crucial. It should be noted that actions to localize and eliminate the consequences of the disasters in Russia are purposefully structured and produce a visible effect. Against this background, the position of transport companies whose actions appear inconsistent does not seem rational. So, on the one hand, Russian Railways Company tried to resolve the crisis situation: an operational headquarters was organized at the Sochi railway station, there was drinking water and the necessary facilities. On the other hand, attempts to solve the problems of passengers, even with the obvious desire of the station staff to help people, did not always look adequate to the situation. So, by speakerphone it was announced that passengers can hand over or reissue tickets for other days and trains. However, no one, including the station head M.S. Levchenko, could confirm or deny that train traffic would be resume from October 26, 2018 or another day.

Then a conflict arose - people filled out applications for ticket delivery in cash and cashless form. At the same time, ticket delivery forms were different. Those who bought tickets for cashless payments, the money was returned to a bank card. It should be reminded that according to the rules of Russian Railways Company, a refund to the payer's account can be up to 30 calendar days [9]. Therefore, people with tickets in their hands were forced to buy new tickets for cash and cashless payments, but it was not possible for everyone, especially for them who was returning from the resort and had no the necessary funds to buy several tickets. This information at the Sochi railway station was confirmed by eyewitnesses during a blitz interview conducted by the author.

Also an unexpected problem for returning vacationers and business travelers was getting certificates on the official delay in Greater Sochi. At first, people stood in line at the Headquarters for more than an hour to get this certificate, but they were informed that the certificates were being given at the inquiry Office. A huge queue also formed there and as a result people received a dubious-looking documents without a seal and the signature.

Information support for the placement of people was not well thought out. Groups of 70 people were formed to be transported by buses to the Olympic Village, to place them in a hotel. Station staff informed people about this. There was nowhere to find out or read more information. Passengers had to gather in groups in the waiting room of the station on the second floor. There the station staff without computer databases or at least information of passenger's flights put people on the list, composing it by hand. In the hall free water, tea, coffee and pate was organized. However, the station staff could not provide people with information about tickets and the opportunity to leave.

Summarizing the difficulties that arose as a result of the natural disaster, we note that in the places of the concentration of the most interested people, i.e. passengers, distinct information about the expected date of resumption of transport links was not announced. Note that this information was published on the Internet, and the dates indicated in it were confirmed. Also, the procedure for reissuing tickets was not announced at the station or in other places, however, at all levels, the station staff replied that passengers should buy new tickets for themselves. Nobody could exchange the tickets, and staff was explaining that such a procedure could not be provided. A Russian Railways Company's staff member answered a direct question about passenger costs that the railway suffered heavy damage as a result of the disaster and was not obligated to bear the costs of reissuing travel documents. Information on the Russian Railways Company's website and a note that could only be obtained from the deputy chief of the station was not clear. In general, the serious assistance provided to passengers was hampered by the poor organization of the processes of accommodation, re-issuing travel documents, and a constant lack of information.

For citizens who decided to leave Sochi by plane using the available tickets, a special situation arose - their applications were considered within 24 hours and they could fly out only to Moscow and St. Petersburg. Next, the passengers themselves had to find the means to pay for travel to their place of residence. It was hypothetically possible for citizens to take advantage of this service with tickets for trains on October 24 and 25. The detailed information could be got at a railway ticket office. However, this was not an ordinary text or other explanation, but a barcode for a smartphone with the appropriate program. Therefore, most passengers, especially the elderly ones, were not able to take advantage of this information.

In general, information support for passengers could not be considered satisfactory. Thus, the owners of electronic tickets did not receive any messages about the cancellation of transport traffic that occurred as a result of a natural disaster - neither about the cancellation of the train, nor about the possibility of exchanging an electronic ticket by 
non-cash method. Thousands of people stormed the windows of five ticket offices in order to hand over a ticket and buy another one, the situation in this crowd at a certain stage became close to panic. Calls to the Russian Railways Company's website were 5-7 hours late and were generally not effective [8].

However, the tension was limited mainly by the walls of the station. In the city, the effects of the disasters were quickly eliminated. Only in some cafes, hotels and shops the payment by credit cards was stopped and explained by poor internet connection. On the whole, the supply was not interrupted in the city, public order was maintained. There was no massive panic or protest that ussually occurrs in such situations. The branches broken by a hurricane were quickly removed. Public institutions, urban transport, shops and cafes, spa and cultural and entertainment structures functioned.

One of the indicators of public moods in zones of natural disasters is their reflection in the mass consciousness, generating certain reactions. Socially significant large-scale events usually give rise to a subjective interpretation of their causes, content and consequences, which is embodied not only in the media, but also in rumors, conjectures and other interpretations of reality. Note that social reactions to emergencies and subjective assessments, which include rumors, often affect social stability to a greater extent than the fact of the cataclysm and its real consequences. Experts in the field of rumorology (science of rumors) note that the lack of objective information or the uncertainty of available information increases the intensity of rumor [10, p. 501], which can destabilize the socio-political situation.

There almost was no panic rumors in Sochi in October 2018. Except for the situation among car drivers who wanted to stock up on fuel for the future, believing that there would be a disruption in fuel supply until the roads were open. The authorities' explanations in the media about fuel reserves in the temporarily blocked area were not widespread enough and did not reach their goals. Accordingly, kilometer-long lines appeared at gas stations, and the author of the article could observe them.

A small number of rumors in the situation with the Sochi hurricane is explained by the availability of highquality Internet, which made it possible to obtain information and, in spite of the lack of official information in the places of passenger congestion, people understood the situation. Insufficient coverage of the situation in the "paper" media, such as newspapers or newsletters, which are prefered to use and trusted by representatives of the older generation can be considered a certain flaw.

The studied materials allow us to formulate conclusions and suggestions.

Another natural disaster in the Greater Sochi region showed that the management of infrastructures and various types of support in the city has been established, the situation is under control of law enforcement, administrative, economic and other structures which are able to provide adequate measures in emergency situations. According to experts, the administrative and managerial structures of Greater Sochi have developed the necessary algorithms for action in emergency situations, which are a result of frequent natural disasters in this region, and their experience is worth spreading.

At the same time, it should be recognized that the measures taken by Russian Railways Company to stop and resolve the crisis were not enough for people returning from vacation. Citizens did not have enough information about actions aimed at solving the problem and at least the approximate dates for restoring train traffic and the possibility of returning home. Meanwhile, such information was available. The queues were the result of officials inactivity, the passengers' psychological condition was negatively affected by the unclear prospects of getting home and the need to hand over tickets, although it was obvious in situation of emergency for officials to arrange ticket re-issuance without people's unforeseen expenses.

The reactions of people affected by the disaster, including those who was leaving, remained within normal limits. There was no panic and conflict. However, the situation had a successful conclusion, primarily due to self-discipline and the well-known patience of Russians. Obviously, the interests of passengers should be more thoroughly protected, especially in situations of disaster. It seems appropriate for large transport companies in Russia (Russian Railways Company, Aeroflot and others) to develop algorithms for action in emergency situations, to fix regulations for protection of passengers' interests. In particular, to provide that passengers whose interests are affected by the disaster the opportunity not to hand over but reissue their tickets. In an emergency, people could be allowed to issue a ticket with an open date (until transport links are restored) in order to save passengers from unnecessary procedures for the delivery and purchase of tickets.

Obviously, there is a need to spread an official information on the progress of repair and restoration work, the estimated timing of the resumption of transport links, the probability of a recurrence of disasters, measures to ensure the affected by a natural disaster, etc. Citizens should not be informed only by Internet sources but by traditional media, including radio, newspapers, and print special newsletters.

And last but not least, the priority proposal concerns the need for strategic scientific planning for the development of the urban environment in coastal regions in a rapidly changing climate. The decisive role in this process should belong to specialists in the field of climatology and urban studies, the attention of representatives of the government and public organizations is necessary. The experience of the international urban sustainability research network (Urban Resilience to Extremes, UREx) demonstrates the relevance of rethinking and predicting the effects of climate change, the need to set long-term goals for several decades, even if in modern socio-political conditions they are difficult to implement $[11$, p. 3]. 
Analysis of crisis events in the Greater Sochi region, the study of domestic and foreign researches of such situations allow us to draw generalized conclusions.

1. Over the past decades, Russia has formed and provided a system for the prevention of disasters and localization of consequences. Archive materials indicate that the Soviet period was characterized by a massive use of available forces and means - up to military equipment, army formations, etc., with the general confidentiality of information about the natural hazard. The latest period is characterized by the creation of the necessary legal framework and a unified state system for preventing and eliminating emergencies.

2. Information support for relevant measures needs to be seriously improved. The shortcomings of proactive public warning of disaster risks are being overcome, but so far ineffective methods prevail. So, the excessively frequent sending of SMS alerts about possible disasters, most of which are not confirmed, give rise to distrust of such warnings. The lack of timely and sufficiently complete information contributes to the formation of negative rumors about the extent of the disaster and its consequences, the destabilization of the socio-political situation. It is obvious that in case of emergency it is necessary to intensify the work of collecting and disseminating objective information and refuting rumors not only in the official media, but also on the Internet, on popular television and radio channels. It is necessary to centrally monitor the information background and develop adequate measures to maintain socio-political stability.

3. The increasing role of local communities in Russia does not yet have a noticeable effect. The actions of political parties and public organizations are often aimed at improving their rating, rather than organizing substantive measures. Meanwhile, local communities have significant potential in this direction, especially in preventive work in preparation for natural hazards.

4. It is necessary to establish a system of compulsory insurance in the event of a disaster. Pilot projects should be tested in the south of Russia, where disasters with large-scale consequences are most frequent.

5. The safety of the population and facilities during the natural hazard depends on the diversity of the economy, providing access to basic socio-economic infrastructures, such as communications, transport, water supply, and the services of healthcare institutions.

Conclusion. Based on the above findings, it can be assumed that the plans and prospects of management in hazardous events and natural disasters will correspond to the modern world trend - the creation of computer models of natural disasters in specific settlements, correlated with the analysis of geodemographic processes in the region [12, $\mathrm{p}$. 61]. This will allow to work out the options for risks and the development of security threats, to form effective scenarios for the implementation of the necessary measures.

These include analysis of existing and development of new routes, taking into account the ways and means of moving people from the coast to protect against floods, the proactive construction of artificial reefs and dams, the creation of vegetable barriers, water pumping systems and reservoirs, as well as other infrastructure facilities to increase the sustainability of the population item. Managed evacuation plans should also take into account the likelihood of conflicts of interest between various social groups and organizations that could lose property and incur financial damage in a disaster. The mentioned moments suggest the construction of a complex model of the city and its periphery, which makes possible the spatial design of the parameters of the settlement in the changing environmental conditions.

\section{Acknowledgments}

This work was prepared as a part of the RFBR grant "Dangerous natural phenomena and social processes in the Black Sea, Priazovye and Caspian Regions: problems of interdependence and mutual conditionality." (No. 18-05-80043).

\section{ЛИТЕРАТУРА}

1. James Daniell, Friedemann Wenzel, Andreas Schaefer. The economic costs of natural disasters globally from 1900-2015 // Geophysical Research Abstracts Vol. 18, EGU2016-1899, EGU General Assembly 2016.

2. Матишов Г.Г. Керченский пролив и дельта Дона: безопасность коммуникаций и населения // Вестник Южного научного центра. Том 11, № 1, 2015. С. 6-15.

3. Бек У. Общество риска. На пути к другому модерну. М.: Прогресс-Традиция, 2000. - 384 с.

4. Руководство по снижению риска стихийных бедствий на уровне сообщества в Центральной Азии. Geneva. UNDRR (UN Office for Disaster Risk Reduction), 2006. $36 \mathrm{c}$.

5. Ситуация в Туапсе и Сочи после наводнения 25 октября 2018 года (видео, факты) // Сайт «Геленджик: от Кабардинки до Тешебса», 25.10.2018. URL: http://yug-gelendzhik.ru/situaciya-v-tuapse-i-sochi-posle-navodneniya-25-oktyabrya-2018goda/ (дата обращения 05.01.2020).

6. Сводки ГУ МЧС России Краснодарскому краю, октябрь 2018 г. URL: http://23.mchs.gov.ru/operationalpage/digest/2018/10/ (дата обращения 05.01.2020).

7. 36 посздов отменено из-за наводнения в Сочи // Информационное агентство REGNUM, 26.10.2018. URL: https://regnum.ru/news/2508124.html (дата обращения 05.01.2019).

8. Интервью очевидца Карыцевой В.В., 1972 г.р., продолжительность 27 минут, записано в железнодорожном вокзале г. Сочи 26.10.2018 г
9.
Возврат
электронных
билетов
на
сайте
OAO
"РжД".
URL:

http://pass.rzd.ru/static/public/ru?STRUCTURE_ID=5238 (дата обращения 10.01.2020).

10. Allport G.W., Postman L. An analysis of rumor // The Public Opinion Quarterly. 1946-1947. V. 10. - № 4. - PP. 501. 
11. Vaidyanathan G. Science and Culture: Imagining a climate-change future, without the dystopia // Proceedings of the National Academy of Sciences of the USA, PNAS. December 18, 2018. № 115 (51). P. 1-4.

12. Дружинин А.Г. Геоэкономические и геополитические аспекты современного развития городов Причерноморья // Научная мысль Кавказа, 2018. № 1 (93). С. 61-69.

\section{REFERENCES}

1. James Daniell, Friedemann Wenzel, Andreas Schaefer. The economic costs of natural disasters globally from 1900-2015 // Geophysical Research Abstracts Vol. 18, EGU2016-1899, EGU General Assembly 2016.

2. Matishov G.G. Kerchensky proliv i delta Dona: bezopasnost kommunikatsy i naseleniya // Vestnik Yuzhnogo nauchnogo tsentra. Tom 11, № 1, 2015. S. 6-15.

3. Bek U. Obshchestvo riska. Na puti k drugomu modernu. M.: Progress-Traditsiya, 2000. $384 \mathrm{~s}$.

4. Rukovodstvo po snizheniyu riska stikhiynykh bedstvy na urovne soobshchestva v Tsentralnoy Azii. Geneva. UNDRR (UN Office for Disaster Risk Reduction), 2006.36 s.

5. Situatsiya v Tuapse i Sochi posle navodneniya 25 oktyabrya 2018 goda (video, fakty) // Sayt «Gelendzhik: ot Kabardinki do Teshebsa), 25.10.2018. URL: http://yug-gelendzhik.ru/situaciya-v-tuapse-i-sochi-posle-navodneniya-25-oktyabrya-2018-goda/ (data obrashcheniya 05.01.2020).

6. Svodki GU MCHS Rossii Krasnodarskomu krayu, oktyabr 2018 g. URL: http://23.mchs.gov.ru/operationalpage/digest/2018/10/ (data obrashcheniya 05.01.2020).

7. 36 poyezdov otmeneno iz-za navodneniya v Sochi // Informatsionnoye agentstvo REGNUM, 26.10.2018. URL: https://regnum.ru/news/2508124.html (data obrashcheniya 05.01.2019).

8. Intervyu ochevidtsa Karytsevoy V.V., 1972 g.r., prodolzhitelnost 27 minut, zapisano v zheleznodorozhnom vokzale g. Sochi 26.10.2018 g.

9. Vozvrat elektronnykh biletov na sayte OAO "RZHD". URL: http://pass.rzd.ru/static/public/ru?STRUCTURE_ID=5238 (data obrashcheniya 10.01.2020).

10. Allport G.W., Postman L. An analysis of rumor// The Public Opinion Quarterly. 1946-1947. V. 10. № 4. P. 501.

11. Vaidyanathan G. Science and Culture: Imagining a climate-change future, without the dystopia // Proceedings of the National Academy of Sciences of the USA, PNAS. December 18, 2018. № 115 (51). P. 1-4.

12. Druzhinin A.G. Geoekonomicheskiye i geopoliticheskiye aspekty sovremennogo razvitiya gorodov Prichernomorya // Nauchnaya mysl Kavkaza, 2018. № 1 (93). S. 61-69.

\section{OБ ABTOPAX | ABOUT AUTHORS}

Семенов Василий Станиславович, кандидат политических наук, научный сотрудник лаборатории политических исследований Федерального исследовательского центра Южного научного центра Российской академии наук, 344006 г. Ростов-на-Дону, пр. Чехова, 41, т. 8-989-618-91-48, semenov unc@mail.ru

tory,

Semenov Vasily Stanislavovich, Candidate of Political Sciences, Researcher at the Political Research Labora-

Federal Research Center, The Southern Scientific Center, Russian Academy of Sciences, 344006, Rostov-on-

Don,

41 Chekhov Ave., tel. 8-989-618-91-48, semenov_unc@mail.ru

Семенова Ольга Валерьевна, кандидат философских наук, научный сотрудник лаборатории истории и этнографии Федерального исследовательского центра ІОжного научного центра Российской акаде-

мии

наук, 344006 г. Ростов-на-Дону, пр. Чехова, 41, т. 8-918-515-84-98, oliko_sov@mail.ru

Semenova Olga Valerievna, $\mathrm{PhD}$ in Philosophy, Researcher at the Laboratory of History and Ethnography, Federal Research Center, The Southern Scientific Center, Russian Academy of Sciences, Rostov-on-Don, 344006 ,

41 Chekhov Ave., tel. 8-918-515-84-98, oliko_sov@mail.ru 